\title{
THE DOCTRINAIRE AUTHORITY: THE COURT OF JUSTICE OF THE EU AND THE FUNDAMENTAL RIGHTS
}

\author{
Goran Ilik ${ }^{1, *}$ \\ ${ }^{1}$ University St. Kliment Ohridski - Bitola, Faculty of Law \\ Rudnička Street, Kičevo, Republic of Macedonia
}

\begin{abstract}
:
This paper represents the analysis of the Court of Justice of the EU, in particular the Court of Justice, and its "interpretive power", within its authority for diffusion and proliferation of the EU law. Namely, the paper describes the position, responsibilities, powers and the role of the Court of Justice, in order to penetrate into its institutional performances as doctrinaire authority, regarding the Charter of Fundamental Rights of the EU as its interpretive framework. Also, the paper presents the most representative axiological determinations of the EU as a basis of the "interpretive power" of the Court of Justice. Accordingly, the paper describes the Court as a central judicial EU institution that with its "interpretive power" generates legal doctrines through the prism of fundamental rights and freedoms. Consequently, the Court of Justice appears as undisputed doctrinaire authority that assumes the role of doctrine - maker and doctrine - keeper of the human rights and freedoms, accepted and promulgated by the EU.
\end{abstract}

\section{Key words:}

EU,

"interpretive power",

doctrine,

fundamental rights.

\section{INTRODUCTION}

This paper represents the analysis of the legal position of the Court of Justice of the European Union (CJEU) and its work within the process of making / producing legal doctrines, which at the same time represents the basis for creation, application and improvement of the European Union law in general. It deals with the doctrine of direct effect, the doctrine of supremacy (of the EU law), the doctrine of implied powers and the doctrine of human rights. This paper devotes special attention to the doctrine of human rights, as a doctrine that directly stems from the axiological determination of the Union, even more amplified with the incorporation of the EU Charter of Fundamental Rights within the Lisbon Treaty, as an interpretive framework. With respect to that, the CJEU appears as a central EU institution, fully authorised for interpretation of the constitutive treaties, the acts of the EU institutions and bodies and other regulative, adopted by the institutions or bodies of the EU. Reaffirmed by the Lisbon Treaty, The CJEU appears as very complex multi-level judicial structure, stratified on the following levels: the Court of Justice (The Court), the General Court and the Civil Service Tribunal. Since the establishment of the Court of Justice of the European Union in 1952 , its mission has been to ensure that "the law is observed" "in the interpretation and application" of the Treaties (CURIA, 2013). Otherwise, this paper will devote particular attention to the work of the Court of Justice, starting from the fact, that by its existence and functioning it enables the communication between the judicial institutions of the Union and those of the Member States. The Civil Service Tribunal shall not be included in this analysis, as it is the primarily responsible for the settlement of disputes "between the Union and its officers, including the disputes between all bodies or agencies and their officials whose solving competence is transferred to 
the Court of Justice of the European Union" (Ilik, 2012, p. 131). Furthermore, this paper shall present the functional dimension and prerogatives of the Court of Justice, and its "interpretive power" derived from the EU axiological set and its constitutive treaties, aspectuated through the EU Charter on Fundamental Rights as a framework or "engine fuel" for doctrine - making.

\section{THE AXIOLOGICAL BASIS OF THE "INTERPRETIVE POWER"}

In accordance with the aim for promotion, affirmation, and proliferation of the EU law, the Court possesses specific "interpretive power", which directly arises from the EU constitutive treaties, which essentially regulates its normative framework, the legal structure and its prerogatives as a central judicial actor, armed with interpretive power. In that context, we define the meaning of the "interpretive power", as a specific legal and institutional capacity of the Court of Justice for taking legal and intellectual actions that involve perception, articulation and direct applicability of the EU treaties and legal documents in the spirit of European unification. The Oxford Dictionaries define interpretation as "[an] action of explaining the meaning of something" (Oxford, 2013), and thus, the "interpretive power" within the paper can be summarized as the legal and institutional capacity of the Court directed towards explaining the real meaning of the EU law, in order to ensure diffusion of the EU law to the Member States.

The crucial aim of the "interpretation" by the Court is directed towards uniform application of the EU law. In this sense, the exercise of the "interpretive power" by the Court aims to produce doctrine of human rights and apply it to the Member States legal reasoning and behaviour. Consequently, using the EU Charter on Fundamental Rights as framework or "engine fuel" for doctrine - making, the Court makes a significant step forward, towards legally confirming / recognising the importance of the human rights and freedoms for the EU and its civilisational mission.

Accordingly, the axiological basis of the "interpretive power" of the Court certainly springs from the fundamental rights and freedoms, as basic tenets of the creation, the existence and the functioning of the EU as such. Moreover, the Lisbon Treaty reaffirms the Union as a major promoter and keeper of the fundamental values of humanity (according to the EU constitutive treaties) especially in the Article 21, as follows: "democracy, the rule of law, the universality and indivisibility of human rights and fundamental freedoms, respect for human dignity, the principles of equality and solidarity, and respect for the principles of the United Nations Charter and international law" (European Union, 2008). Consequently, we can freely conclude that the Union primarily rests on the axiological set (set of values) which includes: respect of human dignity, fundamental freedoms and rights, the rights of the communities and family, freedom and liberty, democracy, equality, the rule of law, social justice, etc. Those values make the Unions' identity distinctive and genuine compared to other international actors, within the area of human rights and freedoms. Accordingly, the Union appears as a strong supporter, promoter and keeper of the previously mentioned values, which directly concerns the fundamental rights. In addition, regarding the fundamental rights, it is useful to stress that the Article 6 of the Lisbon Treaty, stipulates the following: “The Union recognises the rights, freedoms and principles set out in the Charter of Fundamental Rights of the European Union of 7 December 2000, as adapted at Strasbourg, on 12 December 2007, which shall have the same legal value as the Treaties. The provisions of the Charter shall not extend in any way the competences of the Union as defined in the Treaties. The rights, freedoms and principles in the Charter shall be interpreted in accordance with the general provisions (...) its interpretation and application and with due regard to the explanations referred to in the Charter, that set out the sources of those provisions" (European Union, 2008).

\section{THE ROLE OF THE COURT OF JUSTICE}

As regards the Court of Justice, it is primarily necessary to locate the role, competencies and position of the Court of Justice of the European Union. Therefore, in accordance with the Article 19 of the Lisbon Treaty, The Court of Justice of the European Union shall, in accordance with the Treaties:

1. rule on actions brought by a Member State, an institution or a natural or legal person;

2. give preliminary rulings, at the request of courts or tribunals of the Member States, on the interpretation of Union law or the validity of acts adopted by the institutions; and

3. rule in other cases provided for in the Treaties (European Union, 2008). 
From this enumeration stems the position of the Court of Justice of the EU, as judicial institution located "above" the national courts, which is activated by Member States initiative or submission of the particular procedure or request for interpretation to the Court of Justice, in order to harmonise the EU law with that of the Member States. Thus, it distinguishes between the concepts of the supremacy and superiority of the Court of Justice of the EU in relation to the Member States courts, but only on doctrinaire / interpretive level, as the Court of Justice does not possess the capacity to revoke decisions of the lower courts (as lower judicial instances). Consequently, the CJEU appears as keeper of the doctrine of fundamental human rights, but not as a supreme or constitutional court of the Union, but as a doctrinaire authority. However, with the strengthening of the position and role of the Court of Justice of the EU, the Lisbon Treaty makes the link between the Court and the courts of the Member States more vertical and multilateral.

The relationship became vertical because the CJEU acquires superior position in relation to national courts, and thereby, initiates the national courts as enforcers of the EU law. Accordingly, the relationship has become more multilateral, since the entire CJEU rulings started to influence equally all national courts without exception. Consequently, it is necessary to emphasise that the decisions of the Court of Justice of the EU have only doctrinaire effects, not compulsory. As the "interpretive power" of the Court is manifested through the doctrine making and that means explaining the meaning of the spirit of the EU law. In that context, the Court requires from the Member States only to implement the national legislative, litigations and norms in the spirit of EU law as precondition for establishing an authentic and decentralised EU legal system. In addition, as an instrument for the realization of the competencies, the Court of Justice adopts preliminary rulings concerning the following:

1. Reviews the legality of the acts of the institutions of the European Union,

2. Ensures that the Member States comply with the obligations under the Treaties, and

3. Interprets European Union law at the request of the national courts and tribunals (European Union, 2008).

Consequently, the author Karen J. Alter (2001, p. 28) argues that: "[t]he central factor that allows the expansion of European law through the legal in- terpretation is the fact that the [CJEU] is an institution positioned outside the domestic contexts of the Member States in which national actors dominate [...] and supranational actors which supplies the capacity to review and national norms and European law". This formulation, unambiguously confirms the current capacity of the Court, regarding its "interpretive power" over the national legislatives, litigations and norms and European law as well. As the Article 19 of the Lisbon Treaty stipulates: "The Court of Justice of the European Union shall include the Court of Justice [...] shall ensure that in the interpretation and application of the Treaties the law is observed. Member States shall provide remedies sufficient to ensure effective legal protection in the areas covered by the Union law" (European Union, 2008). From this position of the Court within the EU legal system derives its sui generis quasi-federal nature, characterised by its legal authority for interpretation, but not with a power to appeal the national norms, litigation or legislation. In addition, through its indisputable "interpretive power", the Court acquires latent political credibility. This kind of credibility does not stem from the fact that the Court is a political body, understood in the classical sense, but from its real action, derived from its "interpretive power" as a power which greatly affects the European integration process through the interpretation and application of the EU law and its diffusion to the Member States. Or as the Lisbon Treaty in Article 260 provides: "If the Court of Justice of the European Union finds that a Member State has failed to fulfil an obligation under the Treaties, the State shall be required to take the necessary measures to comply with the judgment of the Court" (European Union, 2008). In that sense, various authors and legal / political theoreticians treat the Court as a functional "political" EU institution. Consequently, Prof. Michelle Everson emphasised: "The most curious feature of the European Court of Justice, the Court of the European Union, is not that it is a political court, but rather that it has until very recently been so successful in pursuing its political programme of the integration of Europe through law without attracting much public or even expert notice" (Everson, 2010).

In this context, the Court appears as proactive judicial actor, which through the interpretation of the EU law, actively performs latent political networking of the Member States. Starting from this, the Court is attributed an extremely high credit for its significant contribution to the advancement of 
the European integration. Or as author Henri de Waele (2010, p. 12) stressed: "Unquestionably, the activist stance of the [CJEU] has borne great fruit in the past, and much of the success of the Community project can be attributed to it. Nonetheless, the system has witnessed many changes in the past decades, the efficiency has increased, and the other institutions have much improved their democratic record. There is little need any more for the Court to play the part of the "locomotive of European integration". Moreover, the author Fabio Wasserfallen emphasised that: "[The theoreticians Burley and Mattli] called the European Court of Justice a 'hero', who 'signals and paves the way' $[. .$.$] on which the political actors can$ further integration'. Accordingly, the judiciary determines and expands the authority of the [EU] and it becomes 'inevitable' for Member States to follow 'the path chosen"' (Wasserfallen, 2008, p. 8).

Furthermore, it should be noted that the Court is not an "isolated island", but an extremely communicative judicial institution, which functions in continuous communication and cooperation with the courts of the Member States. Namely, as the Lisbon Treaty stipulates: "The Court constitutes the judicial authority of the European Union and, in cooperation with the courts and tribunals of the Member States, ensures the uniform application and interpretation of European Union law" (CURIA, 2013).

Namely, the communication between the national courts and the Court of Justice, in accordance with the constitutive treaties of the EU, is based on the principle of referring effectuated in non-coercive hierarchical communication. This principle highlights the Court quasi-federal sui generis nature, which makes this judicial institution authoritative but not absolute. The national court is the one that makes the decision for referral and the EU Court delivers decisions on the addressed questions, whereas the case is then referred back to the national courts, which need to apply the EU law on the specific case. Consequently, the CJEU in unconstrained way causes the transformation of the national legislation and the judiciary, through its preliminary rulings, which performs targeting and modelling of the national legislation and the judiciary in accordance with the provisions of the EU law. Consequently, the previously mentioned Charter is emerging as an interpretive framework, through which the Court makes legal doctrines, and thus, diffuses the fundamental human rights and freedoms to the Member States, harmonising their legislative, litigations or norms with the EU law in general.

\section{THE EU CHARTER}

\section{AS AN INTERPRETIVE FRAMEWORK}

The Charter of Fundamental Rights of the EU (CFREU) serves as an interpretive framework of the Court of Justice for interpretation of the law, litigations and the issues referred by the Member States, and also, as a basis for proliferation of human rights and freedoms within the EU as a whole. Structurally, this Charter is composed of Preamble, 7 Chapters and 54 Articles, that provide details on human rights and freedoms. Starting from this, the Charter Preamble determines the Member States and the Union as follows: "to strengthen the protection of fundamental rights in the light of changes in society, social progress and scientific and technological development by making those rights more visible in a Charter [...] Conscious of its spiritual and moral heritage, the Union is founded on the indivisible, universal values of human dignity, freedom, equality and solidarity; it is based on the principles of democracy and the rule of law [...]" (European Parlament, 2000, p. 8). Regarding this, the Parties that "signed and sealed" this Charter, determine that the courts of the EU Member States and the Court of the EU will interpret the Charter, relying on the constitutional traditions and international obligations common to the Member States, the European Convention for the Protection of Human Rights and Fundamental freedoms, the social charters adopted by the Union and the Council of Europe, the case law of the European Court of Human rights, and the Court of Justice of the EU as a judicial and doctrinal authority of the Union (European Parlament, 2000, p. 8). Consequently, the fundamental human rights and freedoms stipulated in the Charter are categorised into several chapters, as follows: Dignity $\mathrm{CH}-$ man dignity, Right to life, Right to the integrity of the person, Prohibition of torture and inhuman or degrading treatment or punishment, Prohibition of slavery and forced labour), Freedoms (Right to liberty and security, Respect for private and family life, Protection of personal data, Right to marry and right to found a family, Freedom of thought, conscience and religion, Freedom of expression and information, Freedom of assembly and association, Freedom of the arts and sciences, Right to education, Freedom to choose an occupation and right to engage in work, Freedom to conduct a business, Right to property, Right to asylum, Protection in the event of removal, expulsion or extradition), Equality (Equal- 
ity before the law, Non-discrimination, Cultural, religious and linguistic diversity, Equality between men and women, The rights of the Child, The rights of the elderly, Integration of people with disabilities), Solidarity (Workers' right to information and consultation within the undertaking, Right of collective bargaining and action, Right of access to placement services, Protection in the event of unjustified dismissal, Fair and just working conditions, Prohibition of child labour and protection of young people at work, Family and professional life, Social security and social assistance, Health care, Access to services of general economic interest, Environmental protection, Consumer protection), Citizens' rights (Right to vote and to stand as a candidate in elections to the European Parliament, Right to vote and to stand as a candidate at municipal elections, Right to good administration, Right of access to documents, Ombudsman, Right to petition, Freedom of movement and of residence, Diplomatic and consular protection), Justice (Right to an effective remedy and to a fair trial, Presumption of innocence and right of defence, Principles of legality and proportionality of criminal offences and penalties, Right not to be tried or punished twice in criminal proceedings for the same criminal offence) (European Parlament, 2000 , pp. 9-20). Consequently, through providing these fundamental rights, the Charter appears as an interpretive framework, a prism including human rights and freedoms as its parameters, which must be used for interpretation of legislative, litigations or norms, addressed and submitted to the Court. The aforementioned rights also represent a confirmation of the EU liberal essence, which starts from the position of "giving" more rights and freedoms, while interpreting the submitted legal requests or referrals by the Members States. Furthermore, it is necessary to emphasize that the Court during the process of interpretation produces legal doctrines that are based on the previous fundamental rights that enable the uniform application of the EU law, its improvement, upgrading and its advancement, starting from the case - law based judicial system of the EU (which is mainly based on the previously mentioned doctrines, the effects of the EU law derived from them and the principles of precedent and Acte Clair). Thus, through using of "interpretive power", the Court produces legal doctrines, which in the absence of federal system represent a functional basis for building sui generis legal and judicial system, characteristic to the EU. Besides the mentioned chapters that stipulate the contents of the human rights and freedoms, the Charter also provides the General provisions (Chapter VII) through which it determines, more accurately, the area of its application, the scope of interpretation of the rights and principles, the degree of protection of the fundamental rights and the explicit prohibition of abuse of stipulated rights, as an imperative provision which appeals (Article 54) that: "Nothing in this Charter shall be interpreted as implying any right to engage in any activity or to perform any act aimed at the destruction of any of the rights and freedoms recognised in this Charter or at their limitation to a greater extent than is provided for herein" (European Parlament, 2000, p. 22). Analogously, the provisions of the Charter are directly related to the EU institutions (its agencies, bodies and offices), and the Member States, in a situation when they apply the EU law, and in accordance with the principle of subsidiarity as a fundamental principle in the functioning of the Union as a whole. Also, this Charter reaffirms the position of the European Ombudsman, who acts upon the requests submitted by individuals or legal entities, which have domicile on the EU territory in the cases of human rights and freedoms deprivation or violation, caused due to improper operation of the institutions, bodies, offices and agencies of the EU. In addition, it is essential to emphasise that the process of interpretation and doctrine-making, regarding this Charter, must not be based on the marginalisation, violation or deprivation of the human rights and freedoms stipulated within. The Court of Justice and the Member States must also embrace the moral and legal obligation derived from the stipulated human rights and freedoms, and thus, impose their institutional authority as keepers of those fundamental rights. This particularly refers to the role of the Court of Justice of the EU, which represents a doctrinaire authority based on the EU axiological set and its constitutive treaties, while at the same time appearing as doctrine - maker and doctrine - keeper.

\section{CONCLUSION}

Based on the above mentioned, we can conclude that the Court of Justice of the EU, particularly the Court of Justice in accordance with the competencies and powers provided by the Lisbon Treaty, unambiguously appears as institutional creator of the legal doctrines, founded on the fundamental human rights and freedoms, as doctrine-maker. Namely, the Charter of Fundamental Rights of the EU demar- 
cates the interpretative boundaries and doctrinal parameters of the Court of Justice, without imposing its authority (as absolute) over the judicial instances of the Member States (national) courts of the position of higher instance, understood in a classical sense. Accordingly, the authority of the Court is manifested through its doctrinaire nature as doctrine - maker, as a role derived from its "interpretive power" based on the EU axiological set and its constitutive treaties, and activated by the legal requests and referrals submitted by the courts of the Member States, in the area of human rights and freedoms. Likewise, the Court of Justice of the EU also acts in synergy with the European Court of Human Rights located in Strasbourg, as well as with the provisions of the European Convention on Human Rights, as the basic international document in this field. In that sense, the Court in accordance with the previously mentioned axiological set, the international documents, and the EU constitutive treaties, appears as a doctrinaire authority, articulated through its capacity for doctrine - making, and doctrine - keeping, because the constitutive treaties oblige the Court to fully respect the fundamental rights as the basic interpretive / doctrinaire parameters.

\section{REFERENCES}

Alter, J.K. (2001). Establishing the Supremacy of European Law: The Making of an International Rule of Law in Europe. Oxford: Oxford University Press.

Craig, P. (2008). EU Law: Text, Cases, Materials (4th ed.). Oxford: Oxford University Press.
CURIA: Court of Justice of the European Union. Retrieved February 12, 2013, from http://curia.europa.eu/jcms/ jcms/Jo2_6999/general-presentation

De Waele, H. (2010). The Role of the European Court of Justice in the Integration Process: A Contemporary and Normative Assessment. Hanse Law Review, 6(1), 3-26. Retrieved February 8, 2013, from Hanse Law Review http://www.hanselawreview.org/pdf9/Vol6No01Art01. pdf

European Parlament. (2000). Charter of Fundamental Rights of the European Union. Retrieved February 8, 2013, from http://www.europarl.europa.eu/charter/ pdf/text_en.pdf

European Union. (2008). Consolidated versions of the Treaty on European Union and the Treaty on the Functioning of the European Union. Retrieved February 20, 2013, from http://eur-lex.europa.eu/LexUriServ/ LexUriServ.do?uri=OJ:C:2008:115:0001:01:EN:HTML

Everson, M. (2010). Is the European court of justice a legal or political institution now? Guardian. Retrieved February 18, 2013, from http://www.guardian.co.uk/law/2010/aug/10/european-court-justicelegal-political\#start-of-comments

Interpretation. (2013). In Oxford English online dictionary. Retrieved February 12, 2013, from http://oxforddictionaries.com/definition/english/interpretation?q= interpretation+

Ilik, G. (2012). The Political system and Law of the European Union. Bitola: University St. Kliment Ohridski, Law Faculty.

Wasserfallen, F. (2010). The Judiciary as Legislator? How the European Court of Justice shapes Policy-Making in the European Union. Journal of European Public Policy, 17(8), 1128-1146. DOI: 10.1080/13501763.2010.513559.

\section{DOKTRINARNI AUTORITET: SUD PRAVDE EVROPSKE UNIJE I OSNOVNA PRAVA}

\section{Rezime:}

Ovaj rad predstavlja analizu Suda pravde Evropske Unije, naročito Suda pravde i njegovu "interpretativnu moć" u okviru ovlašćenja za difuziju i proliferaciju prava Evropske Unije. Naime, u njemu se opisuje položaj, ovlašćenja, moći i uloga Suda pravde, kako bi se penetriralo u njegovu institucionalnu suštinu kao doktrinarni autoritet, vezano za Povelju o osnovnim pravima Evropske Unije, kao interpretativni okvir. Takođe, ovaj rad predstavlja i ključne aksiološke odrednice Evropske Unije, kao osnovu “interpretativne moći” Suda pravde. Shodno tome, u radu se Sud pravde opisuje kao centralna pravosudna institucija Evropske Unije, koja preko svoje "interpretativne moći” generiše pravne doktrine kroz prizmu osnovnih prava i sloboda. On se pojavljuje kao neprikosnoveni doktrinarni autoritet u funkciji stvaranja doktrine (doctrine - making) i očuvanja doktrine (doctrine - keeping) ljudskih prava i sloboda, prihvaćenih i proglašenih od strane Evropske Unije.

\section{Ključne reči:}

EU,

"interpretativna moć",

doktrina, osnovna prava.

Received: March 1st, 2013.

Correction: March 27th, 2013.

Accepted: April 15th, 2013. 